\title{
Akumulasi dan Toksisitas Effluen yang Mengandung Kromium pada Ikan Gupi (Poecilia reticulata)
}

\author{
Accumulation and Toxicity of Effluent Containing Chromium on Guppy (Poecilia \\ reticulata)
}

\section{Djohan}

Fakultas Biologi, Universitas Kristen Duta Wacana, Jl. Dr. Wahidin No.5 - 25 Yogyakarta 55224

E-mail: djohan@ukdw.ac.id

\begin{abstract}
Accumulation and toxicity of chromium in leather-tannery effluent on guppies were investigated. An acute (96 hour) static toxicity testing using 5 serial dilution of the effluent was conducted. Each serial dilution consisted of 3 replicates, with each replicate contained 5 litres of diluted effluent and 10 fish. The effluent was diluted $0.2 \%$ to $3.2 \%(\mathrm{v} / \mathrm{v})$. The concentrations of chromium in the diluted effluent and fish range from 0.9 - $9.1 \mu \mathrm{g} . \mathrm{mL}^{-1}$ and 1.4 - $58.9 \mu \mathrm{g} . \mathrm{g}^{-1} \mathrm{w} . \mathrm{w}$, respectively. Bioconcentration factors in this study vary from 1 to 39, with a median value of 6.2. The values of $\mathbf{L C}_{50}$ and ILC $_{50}$ are $4.2 \mu \mathrm{g} \cdot \mathrm{mL}^{-1}$ and $56 \mu \mathrm{g} \cdot \mathrm{g}^{-1} \mathrm{w} . \mathrm{w}$, respectively. The results show that chromium accumulates in guppy and causes acute toxicity. A comparison with the concentrations of chromium in effluent, water, and fish from other studies was also reported.
\end{abstract}

Key words: effluent, chromium, lethal concentration $50 \%\left(\mathrm{LC}_{50}\right)$, internal lethal concentration $\mathbf{5 0 \%}$ (ILC 50 ), guppy, bioconcentration factor

Diterima: 11 September 2008, disetujui: 30 Januari 2009

\section{Pendahuluan}

Kromium merupakan elemen yang secara normal terdapat di dalam tanah dan berada dalam bentuk teroksidasi mulai dari $\mathrm{Cr}$ (II) hingga $\mathrm{Cr}(\mathrm{VI})$ namun yang penting ialah $\mathrm{Cr}(\mathrm{III})$ dan $\mathrm{Cr}(\mathrm{VI})$ yang mempunyai peran bagi biota, dengan $\mathrm{Cr}(\mathrm{VI})$ merupakan jenis krom yang paling toksik (Eisler, 1986). Krom dalam effluen bersumber dari penggunaan sodium kromat dan sodium bikromat dalam aktivitas industri, dengan salah satu sumber kromium dari industri ialah limbah penyamakan kulit (Bosnic et al., 2000). Kromium sebagaimana logam berat lainnya, tidak terdegradasi dalam tubuh biota, dan terakumulasi serta bersifat toksik (USEPA, 1985).

Ikan gupi merupakan salah satu jenis ikan air tawar yang direkomendasikan untuk uji toksisitas akut khususnya untuk uji toksisitas effluen lengkap (whole effluent toxicity testing) (Dorn dan Compernolle, 1995). Data perkembangan fisiologi ikan gupi yang memadai (Chaim, 2004) turut mendukung keperluan ini. Studi tentang akumulasi dan toksisitas kromium pada ikan gupi telah dilaporkan oleh Stary et al., (1982). Kromium (Cr VI) dilaporkan mempengaruhi masa hidup ikan gupi (Perez-Bonito, 2006). Selain itu, pola saturasi kromium dan konsentrasi internal yang mengakibatkan kematian $50 \%$ biota uji (ILC ${ }_{50}$ ) pada Hyalela azteca telah diteliti oleh Norwood et al., (2006) dan Norwood et al., (2007).

Berdasarkan informasi tersebut, diperlukan suatu studi baru yang mengukur agregat toksisitas effluen (sebagai total $\mathrm{Cr}$ ) terhadap ikan gupi. Toksisitas diukur baik terhadap konsentrasi kromium di air yang mengakibatkan kematian 50\% ikan uji $\left(\mathrm{LC}_{50}\right)$ maupun konsentrasi kromium di ikan yang 
mengakibatkan kematian 50\% ikan uji $\left(\mathrm{ILC}_{50}\right)$ Dengan optimalisasi penggunaan $\mathrm{LC}_{50}$ dan ILC $_{50}$, dan observasi respon toksisitas akut ikan gupi terhadap effluen yang mengandung kromium seperti effluen limbah penyamakan kulit, maka diharapkan suatu model biomonitoring limbah industri penyamakan kulit pada biota akuatik dapat dikembangkan. Eisler (1986) melaporkan bahwa $\mathrm{LC}_{50}$ untuk $\mathrm{Cr}$ (VI) pada ikan yang sensitif berkisar antara 0,45 - $2 \mu \mathrm{g} \cdot \mathrm{mL}^{-1}$. Van der Putte et al., (1981) melaporkan bahwa $\mathrm{LC}_{50}$ untuk $\mathrm{Cr}$ (VI) pada ikan Salmo gairdneri adalah 3,4 $\mu$ g. $\mathrm{mL}^{-1}$ (pada pH air 6,5) dan 7,6 $\mu$ g. $\mathrm{mL}^{-1}$ (pada $\mathrm{pH}$ air 7,0).

Memperhatikan hal-hal yang dijelaskan terdahulu, maka penelitian ini dilaksanakan dengan tujuan: (1) mengetahui konsentrasi total kromium dalam effluen suatu pabrik penyamakan kulit, (2) menentukan toksisitas effluen pabrik penyamakan kulit terhadap ikan gupi sebagai $\mathrm{LC}_{50}, \mathrm{ILC}_{50}$ dan waktu yang diperlukan untuk mengakibatkan kematian 50\% populasi ikan uji (lethal time 50\%, $L T_{50}$ ), (3) menentukan faktor biokonsentrasi (FB) yaitu perbandingan antara konsentrasi kromium dalam badan ikan dengan konsentrasi kromium dalam air, dan (4) membandingkan konsentrasi kromium dalam air dan badan ikan dengan nilai baku mutu lingkungan dan data penelitian lain. Penentuan FB merupakan suatu integrasi antara parameter biotik $\left(\mathrm{C}_{\mathrm{B}}\right.$ atau $\left.\mathrm{C}_{\mathrm{B}}{ }^{*}\right)$ dengan parameter fungsi abiotik $\left(\mathrm{C}_{\mathrm{W}}\right)$ sehingga relevan untuk digunakan dalam analisa pada kondisi lingkungan ekologis yang bervariasi dan berbeda.

\section{Metode Penelitian}

Effluen dalam penelitian ini diperoleh dari suatu pabrik penyamakan kulit yang berlokasi di Yogyakarta. Sampel effluent dikoleksi satu kali (single grab) dan tidak dilakukan aerasi. Preparasi effluen dilakukan dengan mengambil $20 \mathrm{~L}$ sampel effluen, diaduk merata selama 20 menit, lalu dibiarkan mengendap selama 3 jam. Bagian yang jernih digunakan untuk seri pengenceran selanjutnya. Air sungai yang diambil dari bagian hulu segmen sungai (up-stream) digunakan sebagai media pengenceran. Konsentrasi effluen $\left(\mathrm{C}_{\mathrm{E}}\right)$ yang digunakan dalam uji pendahuluan ialah $0,2 \% ; 0,8 \% ; 3,2 \%, 6,4 \%$, dan $12,8 \%$. Sebagai kontrol digunakan air sungai yang tidak mengandung effluen. Pada setiap $\mathrm{C}_{\mathrm{E}}$ digunakan 3 akuarium, yang masing-masing berisi 5 liter effluen yang diencerkan. Pengukuran $\mathrm{pH}$ dilakukan sebelum dan sesudah uji toksisitas 96 jam.

Ikan gupi diperoleh dari salah satu pusat pembenihan ikan di Daerah Istimewa Yogyakarta, diaklimasi selama 7 hari untuk penyesuaian dengan kondisi air sungai yang digunakan dalam uji toksisitas. Uji toksisitas dilaksanakan di Laboratorium Ekologi pada Fakultas Biologi Universitas Kristen Duta Wacana di Yogyakarta. Ikan diberi pakan kering (dry feed) setiap hari dan volume air akuarium diperbaharui $2 \mathrm{~L}$ setiap hari, termasuk dengan membersihkan sisa makanan setiap hari. Penelitian ini menggunakan hanya ikan gupi betina memperhatikan perbedaan berat dan panjang badan antara dua jenis kelamin ikan gupi cukup besar (Chaim, 2004), dan pertimbangan bahwa dengan berat badan ikan gupi betina yang lebih besar maka akan lebih mencukupi untuk keperluan analisa $\mathrm{Cr}$ dalam tubuh ikan. Masing-masing akuarium berisi 10 ekor ikan gupi betina dewasa berumur 8 minggu.

Pada uji pendahuluan (96 jam) semua ikan pada $\mathrm{C}_{\mathrm{E}} 6,4 \%$ dan $12,8 \%$ mengalami kematian, sehingga kedua seri pengenceran ini tidak digunakan dalam uji sesungguhnya. Selain itu, semua ikan yang dipakai dalam uji pendahuluan tidak digunakan lagi dalam uji sesungguhnya. Dengan demikian pada uji sesungguhnya dilakukan uji toksisitas pada 1 kelompok kontrol $\left(\mathrm{C}_{\mathrm{E}} 0 \%\right)$ dan 5 kelompok uji yaitu $0,2 \% ; 0,4 \% ; 0,8 \% ; 1,6 \%$; dan $3,2 \%$. Ikan yang mati pada setiap 24 jam dicatat jumlahnya dan selanjutnya diidentifikasi sebagai ikan yang mati sebelum dikoleksi, dan konsentrasi dinyatakan sebagai $\mathrm{C}_{\mathrm{B}}$. Pada akhir uji toksisitas 96 jam, sebanyak 3 ikan gupi yang belum mati dari setiap akuarium diambil untuk diketahui total kadar $\mathrm{Cr}$ pada ikan yang dimatikan setelah dikoleksi dan dinyatakan sebagai $\mathrm{C}_{\mathrm{B}^{*}}$.

Preparasi dan ekstraksi kromium dalam sampel air dan ikan dilakukan di Laboratorium Kimia Fakultas Biologi Universitas Kristen Duta Wacana. Sebanyak 0,9 g berat basah atau 
wet weight (w.w) ikan gupi diekstraksi dengan menggunakan aquaregia digestible method (IPCS, 1988) menggunakan campuran $18 \mathrm{~mL}$ $\mathrm{HCl}$ pekat dan $6 \mathrm{~mL} \mathrm{HNO}_{3}$ pekat, kemudian dipanaskan hingga volume akhir ekstrak mencapai $10 \mathrm{~mL}$. Sampel air akuarium $(50 \mathrm{~mL})$ diekstraksi dengan menggunakan metode yang sama. Selanjutnya sampel dianalisis dengan menggunakan Atomic Absorption Spectrophotometer (AAS) Hitachi Z-8000 di Laboratorium Kimia Fisika Universitas Gadjah Mada. Analisis kromium dilakukan pada panjang gelombang $357,9 \mathrm{~nm}$ dengan kuat arus $7,5 \mathrm{~mA}$ dan fuel $\mathrm{C}_{2} \mathrm{H}_{2}$. Konsentrasi total kromium dalam air $\left(\mathrm{C}_{\mathrm{W}}\right)$ dinyatakan dalam unit $\mu \mathrm{g} . \mathrm{mL}^{-1}$ sedangkan total kromium dalam tubuh ikan $\left(\mathrm{C}_{\mathrm{B}}\right)$ dinyatakan dalam unit $\mu \mathrm{g} \cdot \mathrm{g}^{-1}$ w.w (berat basah).

Data kematian ikan setiap 24 jam selanjutnya digunakan untuk menentukan mortalitas ikan secara kumulatif pada 48 jam, 72 jam, dan akhirnya pada 96 jam. Mortalitas kumulatif dinyatakan dalam persentase (\%), dan $\mathrm{LC}_{50}$ dapat diperkirakan dengan membuat grafik menggunakan logaritma $C_{W}$ atau $C_{E}$ pada absis dan mortalitas kumulatif pada ordinat, dan nilai yang ditunjukkan pada mortalitas 50\% merupakan log $\mathrm{LC}_{50}$ serta $\mathrm{LC}_{50}$ dihitung sebagai anti $\log \mathrm{LC}_{50}$ (Parrish, 1995). Metode yang sama digunakan untuk menentukan $\mathrm{ILC}_{50}$, dengan menggunakan $\mathrm{C}_{\mathrm{B}}$ atau $\mathrm{C}_{\mathrm{B}}{ }^{*}$ pada absis. Penentuan ILC $_{50}$ dilakukan sebagai terapan model saturasi logam berat pada proses bioakumulasi pada biota akuatik sebagaimana yang dilaporkan oleh Norwood et al., (2006). Penghitungan $\mathrm{LT}_{50}$ juga dilakukan dengan cara yang sama namun dengan menggunakan waktu (jam) pada absis. Pemilihan pada proporsi mortalitas $50 \%$ dilakukan karena proporsi tersebut memiliki tingkat kesalahan yang terkecil dalam suatu garis relatif lurus dalam suatu kurva konsentrasi - respon yang berbentuk huruf $\mathrm{S}$ (sigmoid) (Parrish, 1995).

\section{Hasil dan Pembahasan}

Data panjang badan dan berat badan ikan gupi betina yang digunakan dalam uji toksisitas berdasarkan pengukuran pada 60 dari 180 ikan gupi betina pada awal uji sesungguhnya ditampilkan dalam Tabel 1 berikut ini, dan menunjukkan pola hubungan sebagai persamaan eksponensial $\mathrm{L}=41,9 \mathrm{~W}$ 0,41 dengan $\mathrm{L}$ adalah panjang badan $(\mathrm{mm})$ dan $\mathrm{W}$ adalah berat badan ikan (gram). Persamaan tersebut sebanding dengan standar untuk ikan gupi betina yang dilaporkan oleh Chaim (2004) sebagai $\mathrm{L}=43,7 \mathrm{~W}^{0,29}$, yang menjelaskan bahwa data fisiologi panjang dan berat badan ikan gupi betina telah sesuai dengan standar uji laboratorium. Kadar air pada tubuh ikan gupi yang digunakan dalam penelitian ini adalah 70 $\pm 5 \%(\mathrm{n}=8)$. Nilai $\mathrm{pH}$ pada effluen yang diencerkan berkisar antara 6,9 hingga 7,1 atau umumnya tidak bervariasi cukup besar, sebagaimana ditunjukkan dalam Tabel 1.

Tabel 1. Nilai rerata dan standar deviasi pH effluen, panjang badan, dan berat badan ikan gupi.

\begin{tabular}{cccc}
\hline \hline $\mathbf{C}_{\mathbf{E}}(\mathbf{\%})$ & $\mathbf{p H}^{\mathbf{a}}$ & $\mathbf{L}^{\mathbf{b}} \mathbf{( m m )}$ & $\mathbf{W}^{\mathbf{b}} \mathbf{( g )}$ \\
\hline \hline 0,0 & $7,0 \pm 0,2$ & $43,8 \pm 2,8$ & $1,11 \pm 0,16$ \\
0,2 & $6,9 \pm 0,1$ & $44,3 \pm 1,8$ & $1,15 \pm 0,13$ \\
0,4 & $7,0 \pm 0,2$ & $43,0 \pm 2,3$ & $1,05 \pm 0,12$ \\
0,8 & $7,1 \pm 0,1$ & $42,1 \pm 3,4$ & $1,03 \pm 0,14$ \\
1,6 & $7,0 \pm 0,1$ & $44,3 \pm 2,2$ & $1,15 \pm 0,15$ \\
3,2 & $6,9 \pm 0,2$ & $43,7 \pm 2,6$ & $1,09 \pm 0,14$ \\
\hline \hline
\end{tabular}

Keterangan: ${ }^{\text {a) }} \mathrm{n}=3 \quad{ }^{\mathrm{b})} \mathrm{n}=60$. 
Konsentrasi kromium pada effluen yang diencerkan berkisar antara 0,88 - 9,17 $\mu \mathrm{g} \cdot \mathrm{mL}^{-1}$ (Tabel 1). Konsentrasi kromium pada air $\left(\mathrm{C}_{\mathrm{W}}\right)$ pada kelompok kontrol tidak terdeteksi, yaitu lebih rendah dari limit deteksi $0,5 \mu \mathrm{g} \cdot \mathrm{mL}^{-1}$ pada studi ini. Nilai $C_{W}$ meningkat sesuai dengan nilai $\mathrm{C}_{\mathrm{E}}$, meskipun peningkatan tersebut tidak secara proporsional. Konsentrasi kromium pada ikan gupi yang mati pada saat dikoleksi $\left(\mathrm{C}_{\mathrm{B}}\right)$ tidak terdeteksi $\left(<0,1 \mu \mathrm{g} \cdot \mathrm{g}^{-1}\right)$, terukur pada $\mathrm{C}_{\mathrm{E}}$ $0,2 \%$ sebesar $32,4 \mu \mathrm{g} \cdot \mathrm{g}^{-1}$, dan kemudian relatif stabil mulai $C_{E} 0,4 \%$ hingga $C_{E} 3,2 \%$. Nilai $C_{B}$ pada $\mathrm{C}_{\mathrm{E}} 0,2 \%$ dan $0,4 \%$ masing-masing diukur dari 6 dan 7 ikan yang mati pada tiga akuarium sedangkan pada kelompok $\mathrm{C}_{\mathrm{E}} 0,8 \%, 1,6 \%$, dan $3,2 \%$ diukur dari 9 ikan yang mati, masingmasing tiga ekor dari setiap akuarium replikat. Pada ikan yang dimatikan setelah dikoleksi $\left(\mathrm{C}_{\mathrm{B}^{*}}\right)$ konsentrasi kromium berkisar antara 5,8 hingga $8,3 \mu \mathrm{g} \cdot \mathrm{g}^{-1}$. Berdasarkan data pada Tabel 2 dapat diamati bahwa perbandingan antara $C_{B}$ dan $C_{B^{*}}$ berkisar antara 5,4 hingga 9,8.

Hubungan antara $\mathrm{C}_{\mathrm{W}}$ dengan $\mathrm{C}_{\mathrm{B}}$ ditampilkan dalam Gambar 1, dengan bentuk hubungan sebagai non-linier, yang mengikuti suatu persamaan non-linear dengan $\mathrm{R}^{2}$ sebesar 0,87 (Persamaan 1). Nilai $\mathrm{R}^{2}$ yang cukup tinggi ini menandakan bahwa nilai $\mathrm{C}_{\mathrm{B}}$ terutama ditentukan oleh $\mathrm{C}_{\mathrm{W}}$.

$$
C_{B}=\exp \left\{4,189-\left(\frac{-0,546}{C_{W}}\right)\right\} \quad(\text { Persamaan 1) }
$$

Bioakumulasi Cr pada Hyalella azteca berhubungan dengan kematian dan mempengaruhi toksisitas. Berbeda dengan logam berat lain seperti As, Co, dan Mn, maka untuk $\mathrm{Cr}$ konsentrasi toksikan lebih berhubungan dengan respon kematian dibandingkan dengan respon gangguan pertumbuhan atau efek sub-lethal (Norwood et al., 2007). Pola akumulasi kromium pada Hyalela azteca dilaporkan oleh Norwood et al., (2006) yaitu bahwa mulai $\mathrm{C}_{\mathrm{W}}$ sebesar 10.000 nmol. $L^{-1}\left(0,52 \mu \mathrm{g} . \mathrm{mL}^{-1}\right)$ terdapat akumulasi kromium yang relatif stabil pada $C_{B}$ sebesar 1.000 nmol.g ${ }^{-1}\left(52 \mu \mathrm{g} . \mathrm{g}^{-1}\right)$. Kisaran nilai $C_{B}$ pada Norwood et al., (2006) tersebut sebanding dengan nilai $C_{B}$ yang ditemukan dalam penelitian ini. Nilai $C_{B}$ yang lebih besar $5-10$ kali dibandingkan dengan $\mathrm{C}_{\mathrm{B}^{*}}$ (Tabel 2), mengakibatkan kematian ikan uji sebelum masa uji 96 jam berakhir. Nilai $C_{B}$ yang tinggi pada ikan yang mati perlu diinterpretasikan dengan hati-hati (Eisler, 1986).

Ikan yang dimatikan setelah dikoleksi pada akhir periode 96 jam menunjukkan nilai $\mathrm{C}_{\mathrm{B}^{*}}$ yang lebih rendah dibandingkan dengan ikan yang telah mati sebelum dikoleksi (Tabel 2). Hubungan antara $\mathrm{C}_{\mathrm{W}}$ dengan $\mathrm{C}_{\mathrm{B}^{*}}$ ditampilkan dalam Gambar 2 dengan bentuk hubungan sebagai non-linier, yang mengikuti persamaan eksponensial dengan koefisien regresi non-linear $\left(\mathrm{R}^{2}\right)$ sebesar 0,338 (Persamaan 2). Nilai $\mathrm{R}^{2}$ yang rendah ini menunjukkan adanya faktor-faktor selain $\mathrm{C}_{\mathrm{W}}$ yang mempengaruhi $\mathrm{C}_{\mathrm{B}^{*}}$ (akumulasi kromium pada ikan yang dimatikan setelah dikoleksi). Salah satu kemungkinan bahwa sebagian ikan yang mengalami pemaparan terhadap kromium dan tetap hidup dalam jangka waktu tertentu ialah terjadi respon protektif dalam tubuh ikan dengan melibatkan glutathione (Lushchak et al., 2008).

$C_{B^{*}}=\exp \left\{2,088-\left(\frac{-0,294}{C_{W}}\right)\right\}($ Persamaan 2)

Faktor biokonsentrasi (FB) dihitung sebagai rasio antara $C_{B}$ dengan $C_{W}$, yang dihitung dengan menggunakan Persamaan 3 (untuk ikan yang telah mati sebelum dikoleksi) dan Persamaan 4 (untuk ikan yang dimatikan setelah dikoleksi).

$$
\begin{aligned}
& F B=\frac{C_{B}}{C_{W}} \\
& F B=\frac{C_{B^{*}}}{C_{W}}
\end{aligned}
$$

(Persamaan 4) 
Tabel 2. Rerata dan standar deviasi konsentrasi kromium pada air $\left(\mathrm{C}_{\mathrm{w}}\right)$, ikan yang mati pada waktu dikoleksi $\left(\mathrm{C}_{\mathrm{B}}\right)$, dan ikan yang dimatikan setelah dikoleksi $\left(\mathrm{C}_{\mathrm{B}^{*}}\right)$.

\begin{tabular}{|c|c|c|c|c|}
\hline $\mathrm{C}_{\mathrm{E}}(\%)$ & $\mathrm{C}_{\mathrm{W}}\left(\mu \mathrm{g} \cdot \mathrm{mL}^{-1}\right) \mathrm{n}=3$ & $C_{B}\left(\mu g \cdot g^{-1} w \cdot w\right) n=9$ & $C_{B^{*}}\left(\mu g \cdot g^{-1} w \cdot w\right) n=9$ & $\mathrm{C}_{\mathrm{B}} / \mathrm{C}_{\mathrm{B}^{*}}$ \\
\hline 0,0 & Ttd & Ttd & ttd & - \\
\hline 0,2 & $0,88 \pm 0,03$ & $32,4 \pm 2,3^{\mathrm{a}}$ & $6,0 \pm 1,3$ & 5,4 \\
\hline 0,4 & $1,56 \pm 0,05$ & $55,3 \pm 5,6^{\mathrm{b}}$ & $6,9 \pm 0,7$ & 8,0 \\
\hline 0,8 & $2,87 \pm 0,05$ & $57,7 \pm 2,3$ & $5,8 \pm 0,4$ & 9,8 \\
\hline 1,6 & $5,55 \pm 0,21$ & $55,4 \pm 1,3$ & $8,3 \pm 0,7$ & 6,7 \\
\hline 3,2 & $9,17 \pm 0,08$ & $58,9 \pm 4,4$ & $8,2 \pm 0,4$ & 7,2 \\
\hline
\end{tabular}

${ }^{\mathrm{a}} \mathrm{n}=6 ;{ }^{\mathrm{b}} \mathrm{n}=7 \mathrm{ttd}=$ tidak terdeteksi (limit deteksi $0,5 \mu \mathrm{g} \cdot \mathrm{mL}^{-1}$ dan $\left.0,1 \mu \mathrm{g} \cdot \mathrm{g}^{-1}\right)$.

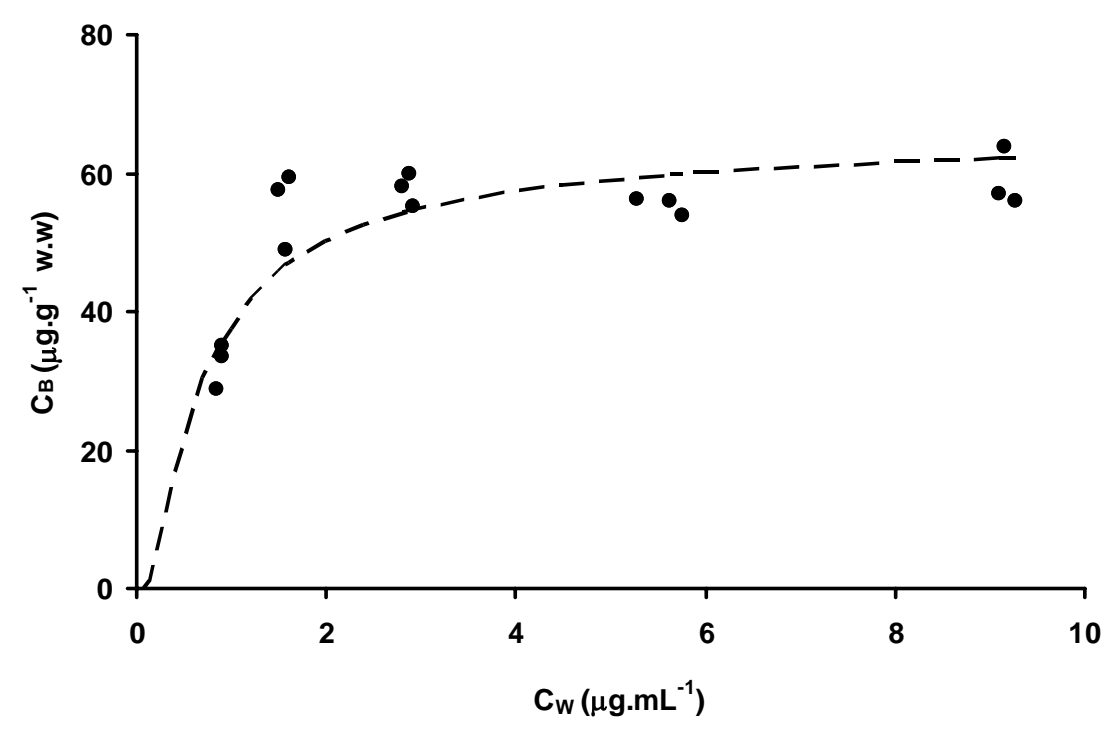

Gambar 1. Hubungan antara konsentrasi Cr dalam air $\left(\mathrm{C}_{\mathrm{W}}\right)$ dengan konsentrasi $\mathrm{Cr}$ dalam tubuh ikan yang mati sebelum dikoleksi $\left(\mathrm{C}_{\mathrm{B}}\right)$.

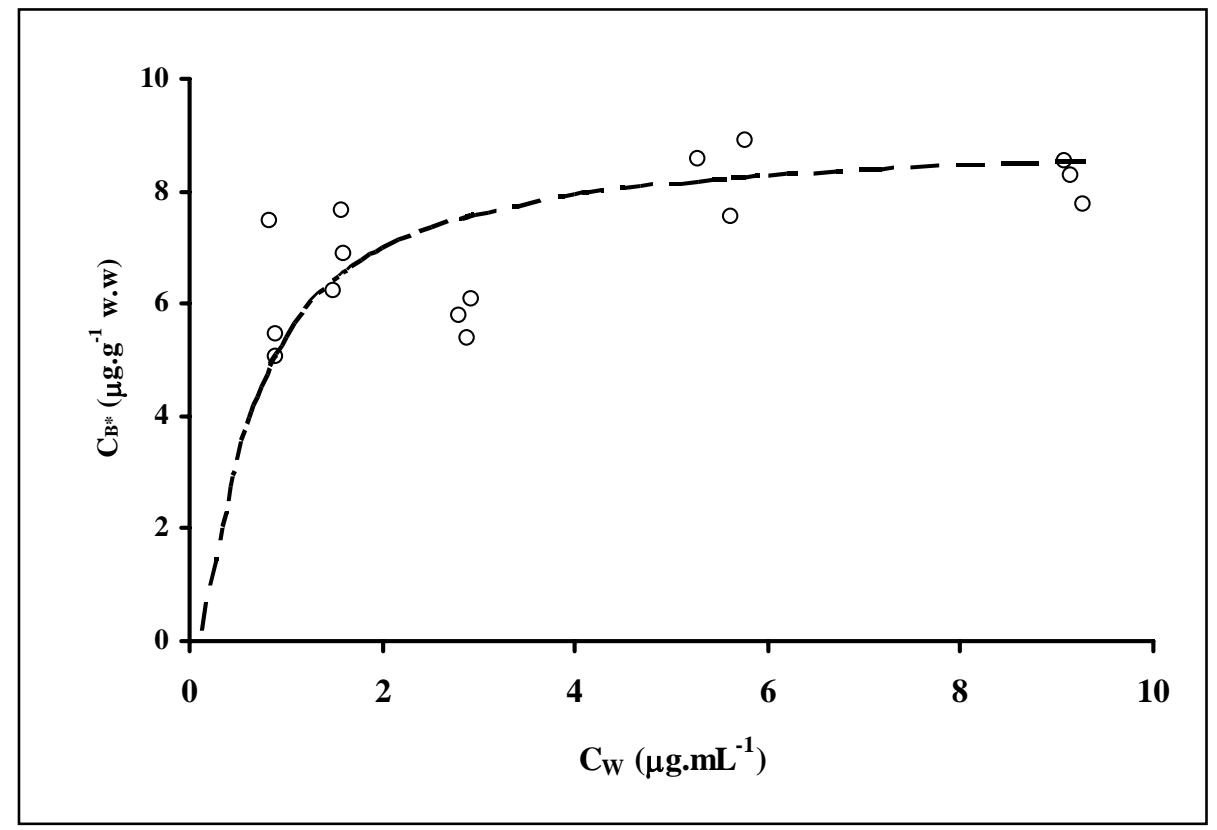

Gambar 2. Hubungan antara konsentrasi $\mathrm{Cr}$ dalam air $\left(\mathrm{C}_{\mathrm{W}}\right)$ dengan konsentrasi $\mathrm{Cr}$ dalam tubuh ikan yang dimatikan setelah dikoleksi $\left(\mathrm{C}_{\mathrm{B}^{*}}\right)$. 
Nilai FB yang dihasilkan dari studi ini berkisar antara 0,9 hingga 39 (Gambar 3). Nilai medium (pada distribusi 50\%) FB yang ditentukan secara grafikal pada Gambar 3 sebesar 6,2. Nilai ini sedikit lebih besar dibandingkan dengan acuan nilai rerata FB kromium sebesar 2, dengan sebaran nilai antara 1 hingga 3,4 (OEHAA, 2000). Sebagian FB yang dihasilkan dari studi ini khususnya bagi ikan yang dimatikan setelah dikoleksi sesuai dengan standar yang direkomendasikan oleh OEHAA (2000). Faktor biokonsentrasi kromium untuk 2 organ dalam yaitu masingmasing pada hati dan insang dilaporkan masing-masing sebesar 2,5 dan 1,5 (Carriquiriborde dan Ronco, 2008).

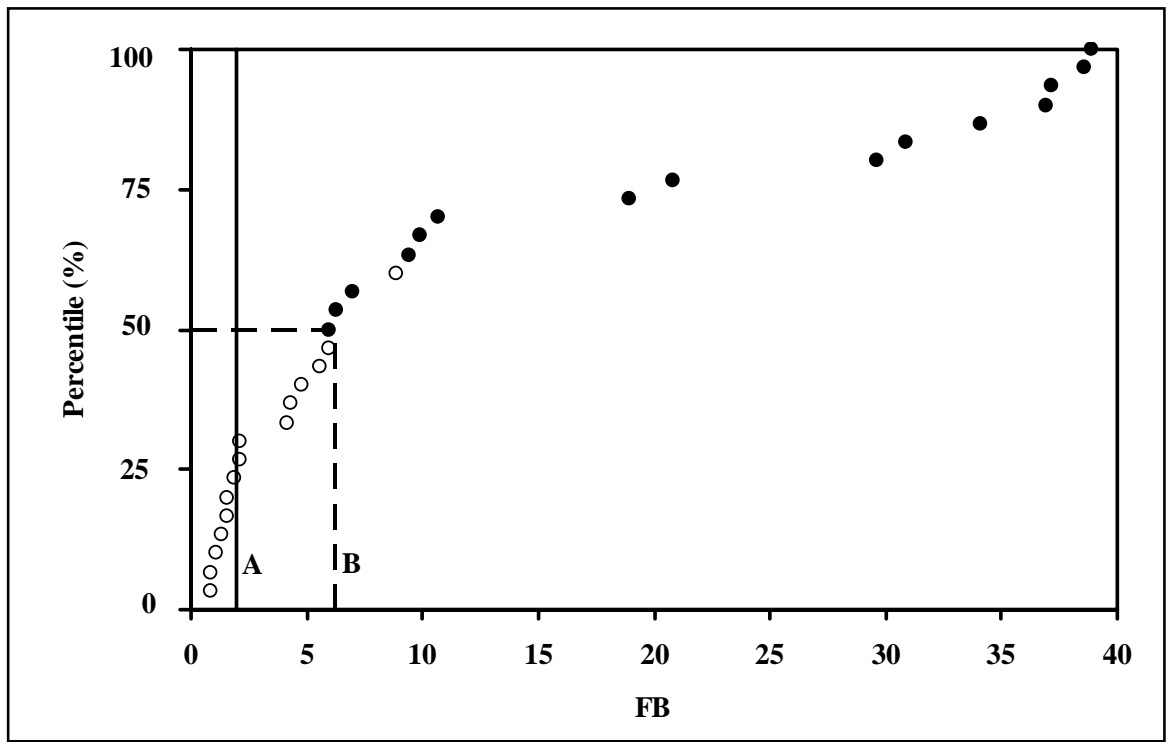

Gambar 3. Distribusi nilai FB (faktor biokonsentrasi) kromium pada ikan yang mati pada waktu dikoleksi (•) dan dimatikan setelah dikoleksi (०), dilengkapi dengan nilai standar menurut OEHAA (2000) (Garis A) dan nilai pada distribusi 50\% pada studi ini (Garis B).

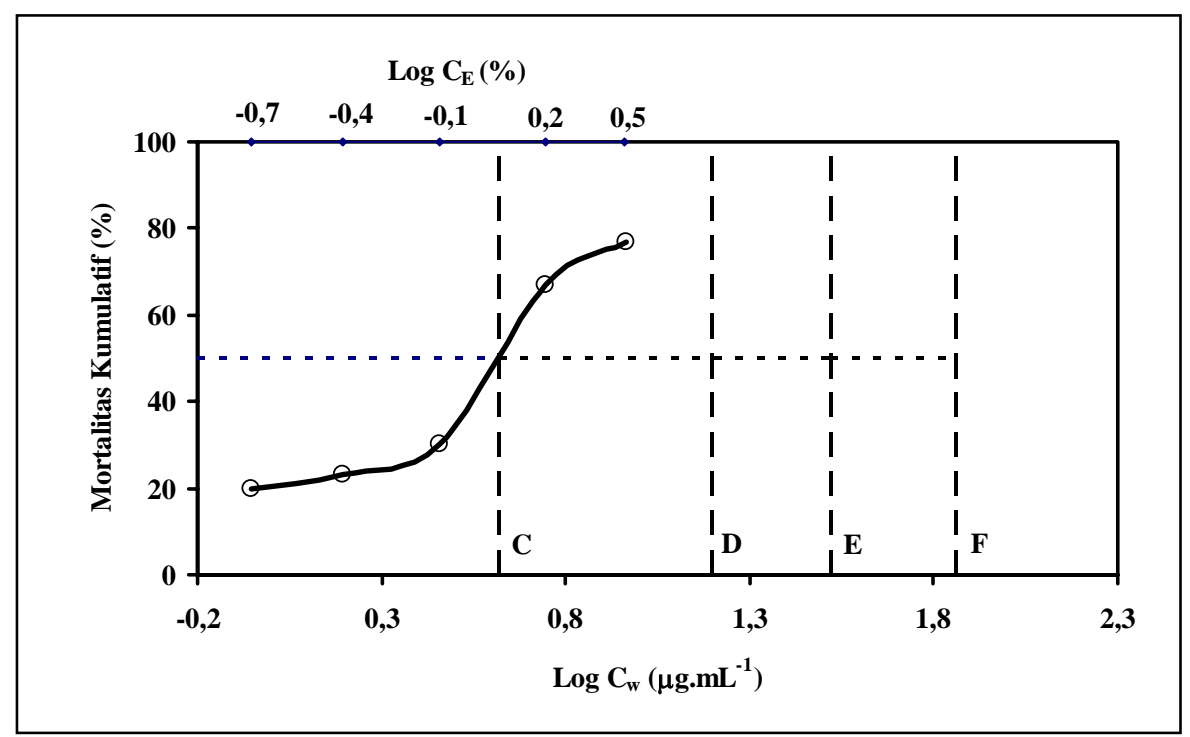

Gambar 4. Kurva hubungan logaritma konsentrasi $C r$ dalam effluen $\left(C_{W}\right.$ dan $\left.C_{E}\right)$ dengan respon mortalitas yang dinyatakan sebagai $\mathrm{LC}_{50}$ pada studi ini (Garis C), dibandingkan dengan $\mathrm{LC}_{50}$ menurut USEPA (1985) (Garis $\mathrm{D}), \mathrm{LC}_{50}$ minimum menurut IPCS (1988) (Garis E), dan $\mathrm{LC}_{50}$ maksimum menurut IPCS (1988) (Garis F). 
Kurva hubungan konsentrasi pemaparan kromium pada ikan gupi dengan respon mortalitas yang berbentuk sigmoid, dan dilengkapi dengan dua jenis aksis yaitu berdasarkan $\mathrm{C}_{\mathrm{E}}$ dan $\mathrm{C}_{\mathrm{W}}$ disertakan dalam Gambar 4. Nilai mortalitas $50 \%$ pada ordinat digunakan sebagai ukuran $\mathrm{C}_{\mathrm{E}}$ atau $\mathrm{C}_{\mathrm{W}}$ yang menyebabkan kematian 50\% ikan uji $\left(\mathrm{LC}_{50}\right)$ yaitu sebesar $4,2 \mu \mathrm{g} \cdot \mathrm{mL}^{-1}$. Nilai tersebut lebih rendah dengan $\mathrm{LC}_{50}$ yang ditentukan oleh USEPA (1985) yang sebesar $16 \mu \mathrm{g} . \mathrm{mL}^{-1}$ untuk $\mathrm{Cr}$ (VI). Nilai tersebut juga lebih rendah dibandingkan dengan $\mathrm{LC}_{50}$ untuk $\mathrm{Cr}$ (III) pada ikan gupi yang berkisar antara $33 \mu \mathrm{g} \cdot \mathrm{mL}^{-1}$ hingga $72 \mu \mathrm{g} \cdot \mathrm{mL}^{-1}$ (IPCS, 1988). Kedua pustaka terakhir merujuk pada uji toksikan tunggal dan tidak untuk banyak toksikan seperti halnya effluen. Sebagai perbandingan lain ialah $\mathrm{LC}_{50}$ kromat $\left(\mathrm{K}_{2} \mathrm{Cr}_{2} \mathrm{O}_{4}\right)$ pada ikan gupi pada uji 7 hari adalah sebesar $66 \mu \mathrm{g}$. $\mathrm{mL}^{-1}$ (PerezBonito, 2006). Toksikan-toksikan lain dalam effluen diperkirakan juga turut mempengaruhi mortalitas ikan sehingga nilai $\mathrm{LC}_{50}$ untuk $\mathrm{Cr}$ yang diperoleh pada studi ini lebih rendah dibandingkan nilai yang dilaporkan pustaka lain. Beberapa kemungkinan kematian ikan yang mengalami pemaparan terhadap kromium adalah inhibisi fungsi sensorik saraf tepi, penurunan aktivitas asetilkolinesterase, ekspansi dan kontraksi rongga mulut dan rongga insang, iritasi pada kulit atau membrana mukosa sehingga meningkatkan aktivitas pergerakan (lokomosi), yang pada akhirnya mempengaruhi metabolisme energi, atau kehilangan sodium melalui urin pada ikan air tawar sehingga mempengaruhi homeostatis elektrolit (Heath, 1995).

Hubungan antara konsentrasi $\mathrm{Cr}$ dalam tubuh ikan gupi $\left(\mathrm{C}_{\mathrm{B}}\right)$ dengan respon mortalitas ditampilkan pada Gambar 5, dan dapat diamati bahwa pada antara $\log \mathrm{C}_{\mathrm{B}}$ 1,74 hingga 1,79 $\mu \mathrm{g} . \mathrm{g}^{-1}$ terjadi peningkatan respon mortalitas dari $23 \%$ menjadi $77 \%$. Nilai $\log \mathrm{ILC}_{50}$ yang ditentukan secara grafikal pada Gambar 5 adalah $1,75 \mu \mathrm{g} \cdot \mathrm{g}^{-1}$ (Garis G) atau sama dengan $\mathrm{LC}_{50} 56 \mu \mathrm{g} \cdot \mathrm{g}^{-1} \mathrm{~W} . \mathrm{w}$, yang ekuivalen dengan 187 $\mu \mathrm{g} . \mathrm{g}^{-1}$ d.w. Sebagai perbandingan dapat digunakan konsentrasi $\mathrm{Cr}$ pada jaringan internal yang menyebabkan kematian 50\% pada Hyalella azteca ialah $334 \mathrm{nmol.g}^{-1}$ d.w atau $17 \mu \mathrm{g} . \mathrm{g}^{-1}$ d.w (Norwood et al., 2006). Dengan demikian dapat diamati bahwa perbedaan $\mathrm{ILC}_{50} \mathrm{Cr}$ pada ikan gupi dengan Hyalella azteca sebesar 11 kali lipat. Perbedaan faktor kelipatan tersebut (one order of magnitude) diperhitungkan dalam perbedaan $\mathrm{LC}_{50}$ antara kelompok taksonomi ikan (Poecilia reticulata) dengan ampipoda (Hyalela azteca) (Suter, 1993).

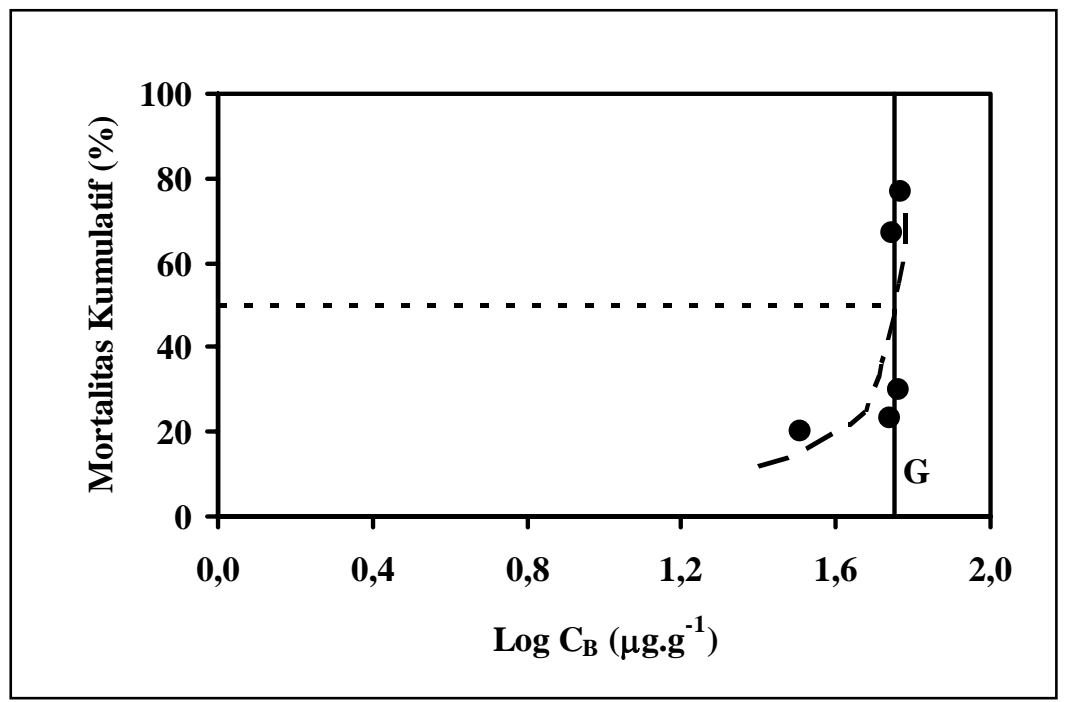

Gambar 5. Kurva hubungan log konsentrasi $\mathrm{Cr}$ dalam tubuh ikan $\left(\mathrm{C}_{\mathrm{B}}\right)$ dengan respon mortalitas pada ikan gupi, dinyatakan sebagai $\mathrm{ILC}_{50}$ (Garis G). 
Kurva hubungan antara waktu kematian (Lethal Time, LT) dengan mortalitas pada ikan ditunjukkan pada Gambar 6. Respon mortalitas kumulatif pada $\mathrm{C}_{\mathrm{E}} 0,2 \%, 0,4 \%$ dan $0,8 \%$ pada akhir uji toksisitas selama 96 jam masingmasing ialah $20 \%, 23 \%$ dan $30 \%$ populasi ikan uji, yang berarti kurang dari $50 \%$, sehingga tidak digunakan untuk penentuan $\mathrm{LT}_{50}$. Selanjutnya nilai $\log \mathrm{LT}_{50}$ ditentukan untuk $\mathrm{C}_{\mathrm{E}}$ $1,6 \%$ dan $C_{\mathrm{E}} 3,2 \%$ secara grafikal dan memberi hasil 1,86 (Garis J) dan 1,89 (Garis K), yang masing-masing sama dengan nilai $\mathrm{LT}_{50}$ sebesar 72 dan 78 jam. Kisaran nilai kedua $\mathrm{LT}_{50}$ tersebut sebanding dengan waktu yang diperlukan untuk mencapai $50 \%$ saturasi kromium pada tubuh ikan Odontesthes bonariensis sebesar 67 jam (Carriquiriborde dan Ronco, 2008), yang ditunjukkan dengan Garis I pada Gambar 6. Skala waktu tersebut sesuai dengan analisa Bosnic et al., (2000) bahwa toksisitas $\mathrm{Cr}$ dalam effluen limbah penyamakan kulit tergolong sebagai toksisitas akut $(\leq 96$ jam) dengan derajat toksisitas sedang sampai dengan berat. Respon adaptif terjadi selama 36 jam pertama yang melibatkan sistem glutation berperan dalam detoksifikasi Cr pada ikan (Luschak et al., 2008). Waktu adaptif 36 jam dinyatakan sebagai Garis $\mathrm{H}$ dalam Gambar 6.

Perbandingan nilai $\mathrm{LC}_{50}$ pada studi ini dengan 3 studi lain tentang konsentrasi $\mathrm{Cr}$ pada badan air yang mengakibatkan efek pada biota akuatik, ditampilkan pada Gambar 7. Dua dari lima konsentrasi $\mathrm{Cr}$ pada $\mathrm{C}_{\mathrm{E}}(0,2$ dan $0,4 \%)$ memiliki nilai yang lebih rendah dari baku mutu $2 \mu \mathrm{g}$. $\mathrm{mL}^{-1}$ (Garis N) yaitu konsentrasi maksimum total $\mathrm{Cr}$ yang diijinkan untuk effluen limbah pabrik kulit di Indonesia (Bosnic et al., 2000). Temuan ini baik dan cocok dengan rekomendasi Dorn dan Compernolle (1995) yaitu bahwa monitoring dilakukan untuk 2 jenis konsentrasi di bawah baku mutu dan 2 jenis konsentrasi di atas baku mutu. Pada Gambar 7 dapat diamati bahwa nilai $\mathrm{LC}_{50}$ pada studi ini (Garis M) lebih besar jika dibandingkan dengan nilai menurut baku mutu (Garis N).

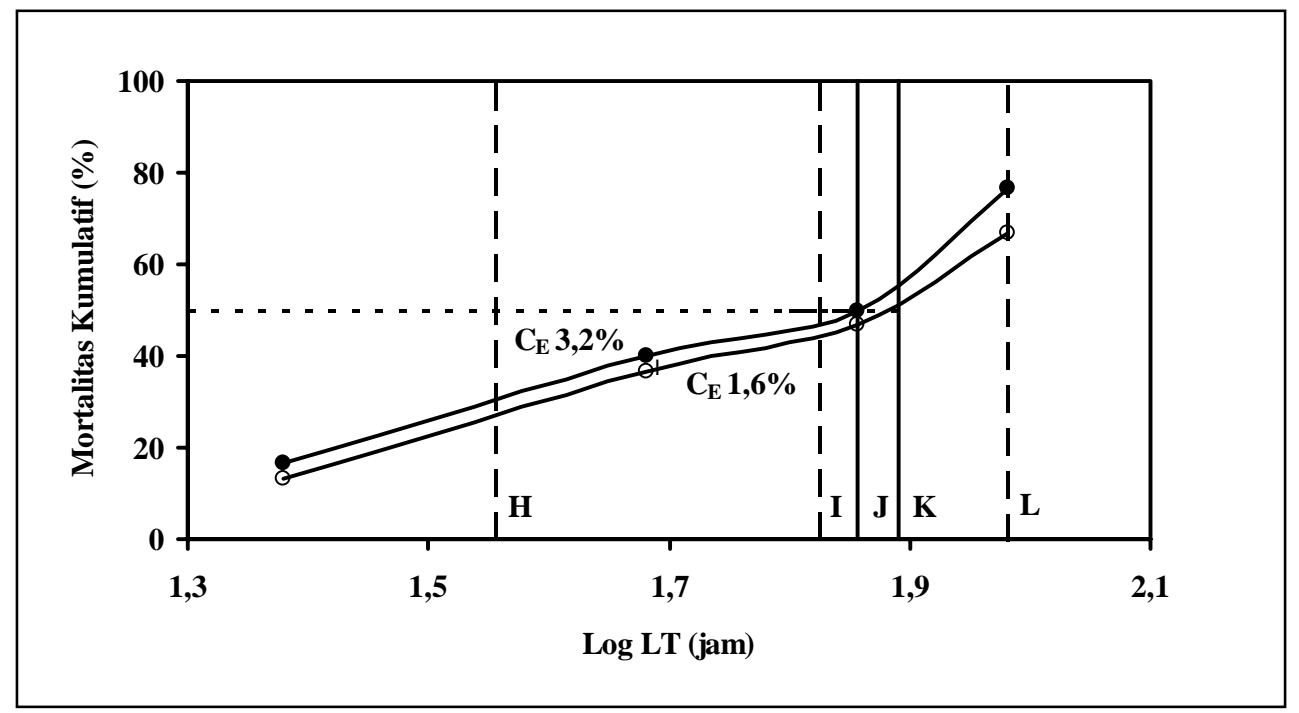

Gambar 6. Kurva hubungan log waktu kematian (Lethal Time, LT) dengan mortalitas kumulatif pada ikan, dengan Garis H merupakan log LT pada $\mathrm{t}=36$ jam, garis I merupakan log $\mathrm{LT}_{50}$ pada ikan menurut Carriquiriborde dan Ronco (2008), garis $\mathrm{J}$ dan $\mathrm{K}$ masing-masing merupakan $\log \mathrm{LT}_{50}$ pada $\mathrm{C}_{\mathrm{E}} 3,2 \%$ dan $1,6 \%$ pada studi ini, dan garis L merupakan merupakan $\log \mathrm{LT}$ pada $\mathrm{t}=96$ jam. 
MATC (Maximum Acceptable Toxicant Concentration) $\mathrm{Cr}$ adalah konsentrasi tertinggi pada saat uji toksisitas yang tidak mengakibatkan efek pertumbuhan, reproduksi, dan keberlanjutan hidup, dengan interval nilai untuk ikan air tawar dilaporkan antara 0,051 $1 \mu \mathrm{g} \cdot \mathrm{mL}^{-1}$ (Eisler, 1986). Konsentrasi $1 \mu \mathrm{g} \cdot \mathrm{mL}^{-}$ ${ }^{1}$ (Garis $\mathrm{O}$, Gambar 7) adalah sebanding dengan nilai terendah pada $\mathrm{C}_{\mathrm{E}} 0,2 \%\left(0,88 \mu \mathrm{g} \cdot \mathrm{mL}^{-1}\right)$ (Tabel 2). Untuk keperluan perikanan, konsentrasi $\mathrm{Cr}$ tidak boleh lebih besar dari 0,025 $\mu \mathrm{g} \cdot \mathrm{mL}^{-1}$ (IPCS, 1988) (Garis P, Gambar 7). Konsentrasi $\mathrm{Cr}$ dalam effluen industri penyamakan kulit dapat sebesar $40 \mu \mathrm{g} \cdot \mathrm{mL}^{-1}$ (IPCS, 1988), dengan konsentrasi $\mathrm{Cr}$ yang umum pada air sungai sebesar $0,001-0,010$ $\mu \mathrm{g} . \mathrm{mL}^{-1}$ (Eisler, 1986).

Perbandingan nilai ILC $_{50}$ pada studi ini dengan Eisler (1986) tentang konsentrasi Cr pada tubuh ikan yang mengakibatkan efek toksik ditampilkan pada Gambar 8. Konsentrasi total $\mathrm{Cr}$ yang lebih besar dari $4 \mu \mathrm{g} . \mathrm{g}^{-1}$ d.w merupakan indikasi telah terjadinya pencemaran (Eisler, 1986). Jika disesuaikan dengan kadar air sebesar $70 \%$ untuk ikan gupi pada studi ini, maka dapat ditentukan indikasi pencemaran sebesar 13,3 $\mu \mathrm{g} . \mathrm{g}^{-1}$ (w.w) (Garis $R)$. Dapat diamati bahwa nilai $C_{B}$ atau $C_{B^{*}}$ lebih besar jika dibandingkan dengan nilai indikasi pencemaran (Gambar 8). Batas maksimum $\mathrm{C}_{\mathrm{B}}$ yang aman bagi ikan adalah sebesar $2 \mu \mathrm{g} . \mathrm{g}^{-1}$ d.w (Eisler, 1986) yang jika disesuaikan dengan kadar air ikan gupi sebesar $70 \%$ pada studi ini, maka sama dengan 6,7 $\mu \mathrm{g} . \mathrm{g}^{-1}$ W.w (Garis S). Pada Gambar 8 dapat diamati bahwa $\mathrm{C}_{\mathrm{B}^{*}}$ lebih rendah dari indikasi pencemaran dan sebanding dengan nilai ambang aman maksimum, sedangkan nilai $\operatorname{ILC}_{50}$ (Garis Q) kurang lebih 4 kali lebih besar dari nilai indikasi pencemaran pada tubuh ikan (Garis R) atau 8 kali lebih besar dibandingkan dengan ambang aman maksimum pada ikan (Garis S).

Kelemahan uji toksisitas lengkap sebagaimana yang dilakukan dalam studi ini ialah pengetahuan tentang toksikan penyebab adalah tidak lengkap dan kondisi di lapangan seperti struktur geokimia sedimen (Davis et al., 1996) dan pola pergerakan ikan (Ramoliya et al., 2007) yang dapat mempengaruhi konsentrasi dan akumulasi Cr. Predator (pemangsa) ikan gupi di lingkungan alami antara lain ialah ikan Rivulus hartii dan Macrobrachium crenulatum (Magurran dan Seghers, 1990). Selain mengakibatkan kematian (mortalitas), kromium juga mengakibatkan gangguan reproduksi dan pertumbuhan pada ikan (Eisler, 1986). Pada kondisi lapangan dan lingkup luas, efek effluen limbah dari kompleks pabrik kulit dilaporkan oleh Financial Daily (2000) telah mempengaruhi produktivitas perikanan (pisciculture) dan pertanian pada daerah tanah rawa di sepanjang Sungai Gangga di India.

Polutan selain $\mathrm{Cr}$ yang umum terdapat dalam limbah penyamakan kulit ialah sulfida, sulfat, ammonia, fosfor, fenol, ammonia, minyak, dan beberapa parameter fisik kimia seperti temperatur, Biological Oxygen Demand (BOD), dan padatan tersuspensi (Bosnic et al., 2000). Polutan-polutan tersebut dapat juga mengakibatkan efek toksik pada ikan gupi yang digunakan dalam studi ini. Secara metodologi, toksisitas gabungan berbagai jenis toksikan dapat dinyatakan sebagai Mixture Toxicity Index (MTI) yang untuk ikan gupi dapat menggunakan contoh studi yang dilaporkan oleh Hermens dan Peter (1982).

Perbandingan antara Cr(III) dan Cr(VI) dalam effluen serta keberadaan senyawasenyawa toksik lain dalam effluen limbah penyamakan kulit juga dapat mempengaruhi hasil akhir. Koefisisen variasi, yang dihitung sebagai (rerata/standar deviasi) x 100\%, pada uji toksisitas akut effluen pada umumnya adalah sebesar 0 - 135\% (intra laboratorium) dan $0-166 \%$ (inter laboratorium), sehingga jika koefisien variasi diperhitungkan untuk kedua jenis perbedaan ini (intra dan interlaboratorium) adalah sebesar $0-300 \%$ (Dorn dan Compernolle, 1995), sehingga dapat digunakan sebagai pertimbangan dalam interpretasi hasil uji. Penentuan nilai parameter pemaparan $\left(\mathrm{C}_{\mathrm{W}}, \mathrm{C}_{\mathrm{B}}, \mathrm{C}_{\mathrm{B}^{*}}, \mathrm{FB}\right)$, hubungan antara $\mathrm{C}_{\mathrm{W}}$ dengan $\mathrm{C}_{\mathrm{B}^{*}}$, dan parameter respon $\left(\mathrm{LC}_{50}\right.$, $\mathrm{ILC}_{50}, \mathrm{LT}_{50}$ ) yang dilengkapi perbandingan dengan beberapa studi lain bermanfaat untuk pengembangan metode biomonitoring efek effluen pada ikan. 


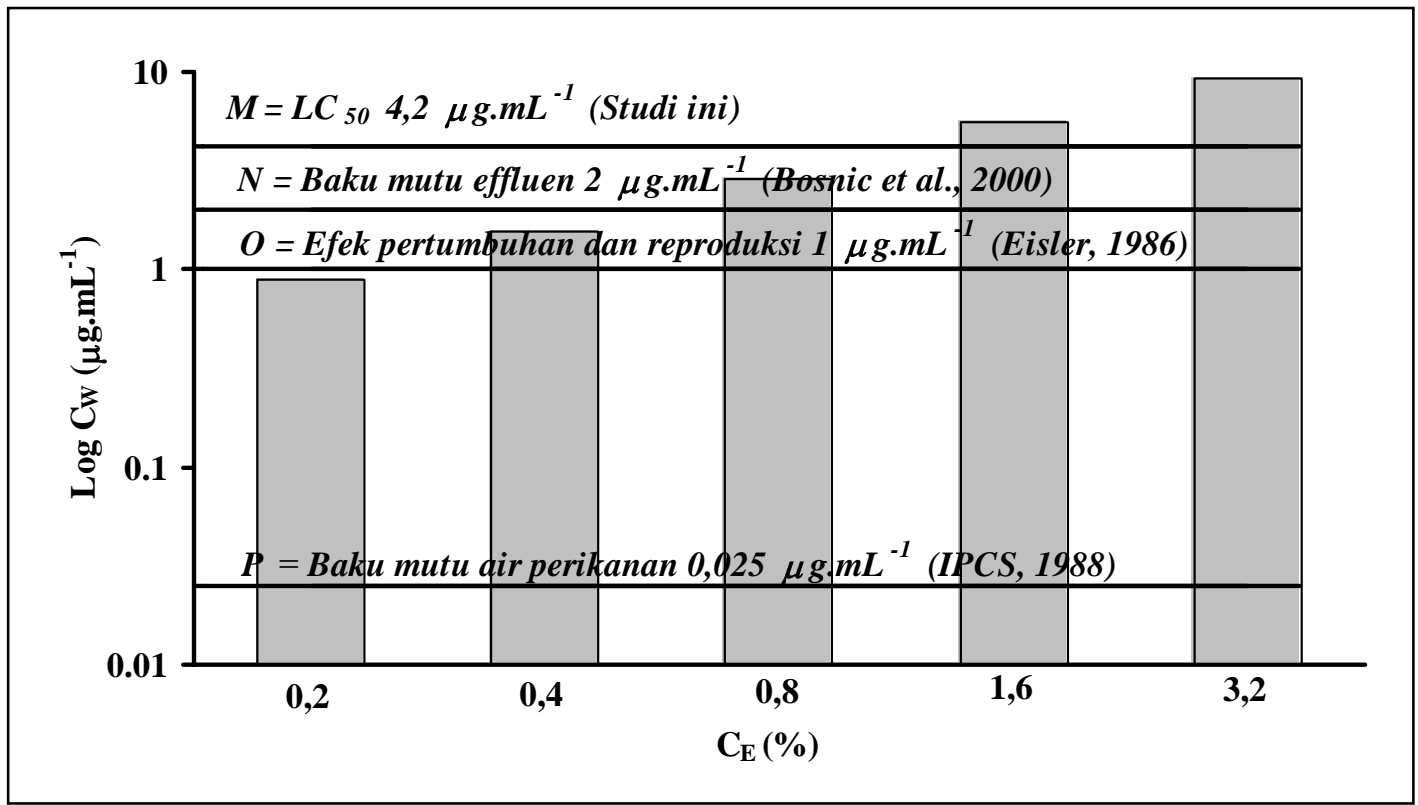

Gambar 7. $\log \mathrm{LC}_{50}$ pada studi ini pada studi ini dan perbandingan dengan baku mutu dari studi lain yang dinyatakan sebagai $\log$ konsentrasi $\mathrm{Cr}$ dalam air $\left(\log \mathrm{C}_{\mathrm{W}}\right)$ dalam perbandingan dengan seri pengenceran effluen $\left(\mathrm{C}_{\mathrm{E}}\right)$.

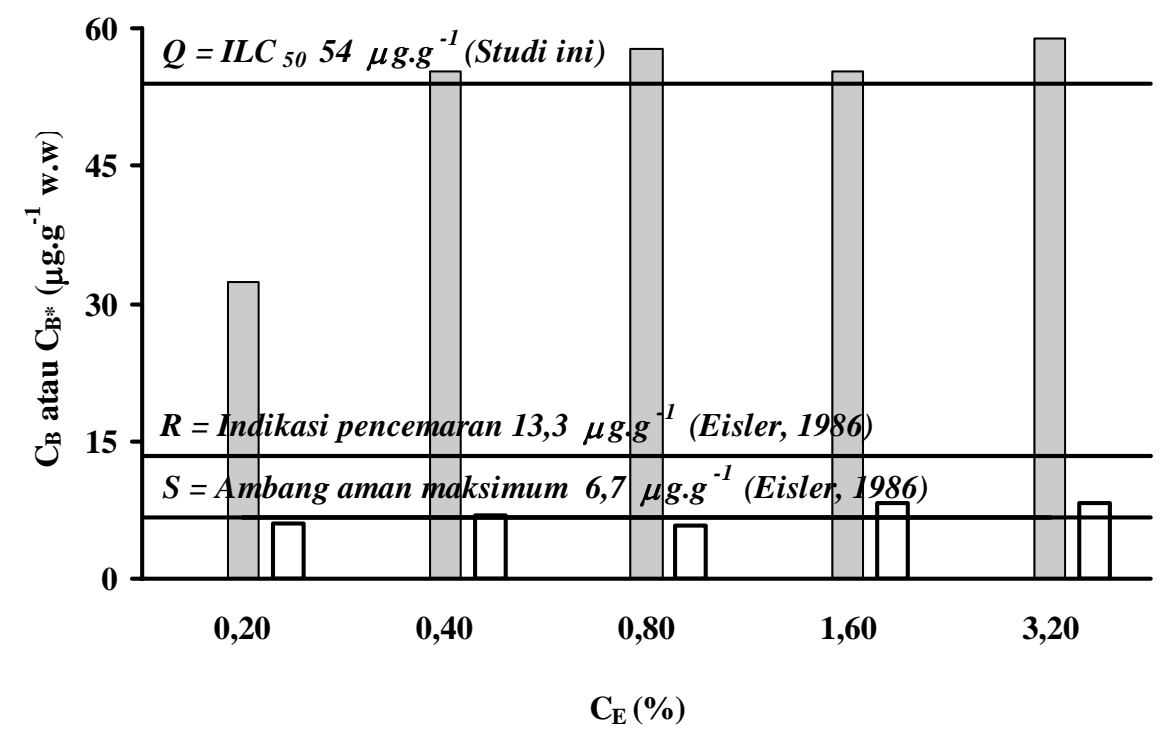

Gambar 8. Konsentrasi kromium dalam tubuh ikan pada studi ini untuk lima seri pengenceran effluen, baik pada ikan yang mati sebelum dikoleksi (bergaris) maupun pada ikan yang dimatikan setelah dikoleksi (polos) dan perbandingannya dengan ILC $_{50}$ pada studi ini serta ambang aman dan ambang tercemar menurut pustaka. 


\section{Kesimpulan dan Saran}

\section{Kesimpulan}

Dari penelitian ini dapat disimpulkan bahwa konsentrasi total kromium pada effluen pabrik kulit dengan pengenceran $0,2 \%$ hingga $3,2 \%$ sebesar $0,9-9,1 \mu \mathrm{g} \cdot \mathrm{mL}^{-1}$, sedangkan konsentrasi total kromium pada ikan gupi betina yang mengalami pemaparan effluen dengan pengenceran $0,2 \%$ hingga $3,2 \%$ adalah $1,4-58,9 \mu \mathrm{g} . \mathrm{g}^{-1}$ w.w. Kromium terakumulasi pada ikan gupi dengan faktor biokonsentrasi sebesar 1 - 39. Nilai $\mathrm{LC}_{50}$ dan ILC $_{50}$ kromium pada ikan gupi, masing-masing sebesar 4,2 $\mu \mathrm{g} . \mathrm{mL}^{-1}$ dan $56 \mu \mathrm{g} . \mathrm{g}^{-1}$ w.w. Nilai $\mathrm{LT}_{50}$ kromium dengan pengenceran 3,2 dan $1,6 \%$ yang terhitung dalam penelitian ini masing-masing sebesar 72 dan 78 jam. Nilai $\mathrm{LC}_{50}$ dan $\mathrm{ILC}_{50}$ pada studi ini lebih besar dibandingkan dengan nilai baku mutu effluen dan indikasi pencemaran pada biota akuatik.

\section{Saran}

Ikan gupi cocok digunakan sebagai salah satu biota untuk uji toksisitas akuatik terhadap effluen pabrik kulit dan juga kemungkian untuk jenis effluen lain. Kombinasi penggunaan $\mathrm{LC}_{50}$, $\mathrm{ILC}_{50}, \mathrm{LT}_{50}, \mathrm{FB}$ sebagaimana yang telah dilaporkan dalam studi ini dapat dikembangkan lebih lanjut sebagai parameter uji untuk keperluan biomonitoring efek effluen pada ikan.

\section{Ucapan Terima Kasih}

Peneliti mengucapkan terima kasih kepada Fakultas Biologi Universitas Kristen Duta Wacana yang telah memberikan bantuan dana penelitian dan dukungan fasilitas bagi penelitian ini. Peneliti juga mengucapkan terima kasih untuk Drs. R. Gunawan Santosa, MSi atas bantuan dalam analisa data regresi non-linear.

\section{Daftar Pustaka}

Bosnic, M., Buljan, J. and Daniels, R.P. 2000. Pollutants in Tannery Effluents: Definitions and Environmental Limits for Discharge into Water Bodies and Sewers. Regional Programme in Tanning Industry in South-East Asia. http://www.unido.org/ fileadmin/import/ userfiles/pufkk/1_pollutants.pdf. 08/15/2008.

Carriquiriborde, P. and Ronco, A.E. 2008. Distinctive Accumulation Patterns of $\mathrm{Cd}(\mathrm{II}), \mathrm{Cu}(\mathrm{II})$, $\mathrm{Cr}(\mathrm{VI})$ in The Tissue of The South American Teleost, Pejery (Odontesthes bonariensis). Aquat. Toxicol. 86 (2): 313-322.

Chaim, S. 2004. Issue II Guppy Labs Index Page. www.guppylabs.info. 08/15/2008.

Davis, A., Sellstone, C., Clough, S., Barrick, R. and Yare, B. 1996. Bioaccumulation of Arsenic, Chromium, and Lead in Fish: Constraints Imposed by Sediment Geochemistry. Appl. Geochem. 11 (3): 409-423.

Dorn, P.B. and Van Compernolle, R. 1995. Effluents. In: Rand, G.M. (Eds.). Fundamentals of Aquatic Toxicology. pp. 903-937.

Eisler, R. 1986. Chromium Hazards to Fish, Wildlife, and Invertebrates: A Synoptic Review. Contaminant Hazard Reviews Report No. 6. Biol. Report 85 (1.6).

Financial Daily. 2000. Calcutta Leather Complex May Hit Wetlands Ecosystem. Thursday, http://www.hindu.com/businessline/2000/08/2 4/stories/142460ub.htm. 08/15/2008.

Heath, A.G. 1995. Water Pollution and Fish Physiology. 2nd Ed. Lewis Publishers. Boca Raton. pp.180-185.

Hermens, J. and Peter, L. 1982. Joint Toxicity of Mixtures of 8 and 24 Chemicals to The Guppy (Poecilia reticulata). Ecotoxicol. Environ. Safety. 6 (3): 302-310.

IPCS (International Programme on Chemical Safety). 1988. Environmental Health Criteria. EHC 61. World Health Organization, Geneva.

OEHAA (Office of Environmental Health Hazard Assessment). 2000. Technical Support Document for Exposure Assessment and Stochastic Analysis. Appendix $\mathrm{H}$ Fish Bioconcentration Factors. pp. H-1-H-5. http://www.oehha.ca.gov/air/hot_spots/pdf/ch ap9.pdf. 08/20/2008.

Lushchak, O.V., Kubrak, O.I., Nykorak, M.Z., Storey, K.B. and Lushchack, V.I. 2008. The Effect of Potassium Dichromate on Free Radical Process in Goldfish: Possible Protective Role of Glutathione. Aquat. Toxicol. 87 (2): 108114. 
Magurran, A.E. and Seghers, B.H. 1990. Population Differences in Predator Recognition and Attack Cone Avoidance in The Guppy Poecilia reticulata. Anim. Behav. 40: (3): 443452.

Norwood, M.P., Borgmann, U. and Dixon, D.G. 2006. Saturation Models of Arsenic, Cobalt, Chromium and Manganese Bioaccumulation by Hyalella azteca. Environ. Pollut. 143: 519528.

Norwood, M.P., Borgmann, U. and Dixon, D.G. 2007. Chronic Toxicity of Arsenic, Cobalt, Chromium and Manganese to Hyalella azteca in Relation To Exposure and Bioaccumulation. Environ. Pollut. 147: 262272.

Parrish, P.R. 1995. Acute Toxicity Tests. In: Rand, G.M. (Eds.). Fundamentals of Aquatic Toxicology. pp. 947-973.

Perez-Bonito, F.J. 2006. Effects of Chromium (VI) and Vanadium (V) on The Lifespan of Fish. J. Trace Elem. Med.Biol. 20 (3): 161-170.
Ramoliya, J., Kamdar, A. and Kundu, R. 2007. Movement and Bioaccumulation of Chromium In an Artificial Freshwater Ecosystem. Ind. J. Exp Biol. 45 (5): 475-479.

Stary, J., Kratzer, K., Prasilova, J. and Vrbska, T. 1982. The Cumulation of Chromium and Arsenic Spescies in Fish (Poecilia reticulate). Int. J. Environ. Anal. Chem. 12 (3-4): 253-257.

Suter, G.W.,II 1993. Ecological Risk Assessment. Lewis Publishers. Boca Raton, USA, pp.175-246.

USEPA (United States Environmental Protection Agency). 1985. Ambient aquatic Life Water Quality Criteria for Chromium 1984. Office of Water Regulations and Standards Criteria and Standards Division. Washington, D. C. EPA 440/5-84/029.

Van der Putte, I., Brinkhorst, M.A. and Koeman, J.H. 1981. Effect of $\mathrm{pH}$ on The Acute Toxicity of Hexavalent Chromium to Rainbow Trout (Salmo gairdneri). Aquat. Toxicol. 1: 129-142. 